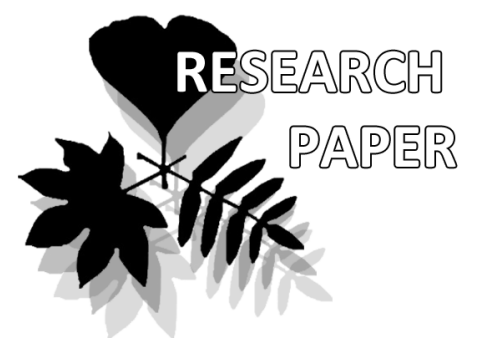

\title{
Position of Ovule Attachment in a Carboniferous Medullosalean Pteridosperm
}

Christopher J. Cleal ${ }^{1}$

e-mail: chris.cleal@museumwales.ac.uk

Mihai E. Popa $2, *$

e-mail:mihai@mepopa.com

${ }^{1}$ Department of Natural Sciences, National Museum Wales, Cathays Park, Cardiff CF10 3NP, U.K.

${ }^{2}$ University of Bucharest, Faculty of Geology and Geophysics, Laboratory of Palaeontology, 010041, Bucharest, Romania

* corresponding author

Manuscript received: 01.08 .2015 Review completed: 25.09.2015

Accepted for publication: 26.09.2015

Published online: 17.10.2015

\begin{abstract}
A B S T R A C T
A specimen of Alethopteris zeilleri from Stephanian deposits of Secu, Reşița Basin of South Carpathians, Romania, provides additional evidence that these medullosalean pteridosperms bore ovules laterally attached to rachises, probably in the proximal part of the frond. Alethopteris zeilleri foliage is associated with Pachytesta incrassata ovules with a peculiar taphonomic position.
\end{abstract}

K e y w o r d s : palaeobotany, Pennsylvanian, Medullosales, ovules, Romania

\section{P E 3 Ю M E}

КАих Х.Аж., Попа М.Э. Поможение места прикрепления семезачатков в каменноугольных медумлозовых семенных папоротниках. Образец Alethopteris zeilleri из Стефанийских отложений близ города Секу, в бассейне Решица (Южные Карпаты, Румыния) представцяет Аополнительные доказательства, что на этих медулмозовых семенных папоротниках семезачатки

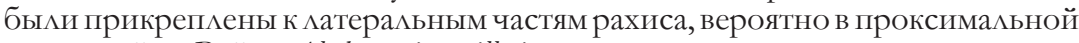
части вайи. Вайи Alethopteris zeilleri находились вместе с семезачатками Pachytesta incrassata в характерном Аля них прижизненном захоронении.

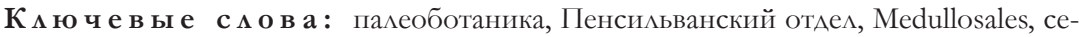
мезачаток, Румыния

Переведено редкомлегией

\section{NTROD U C TIO N}

The Medullosales were a group of now extinct gymnospermous seed plants that flourished in Pennsylvanian (late Carboniferous) tropical wetlands, growing in both clastic and peaty substrates (DiMichele et al. 2006). Remains of their foliage can be found in the deposits of both lowland paralic and "upland" intramontane wetland basins, albeit with different species in the different basin types (Cleal 2008). However, direct evidence of their ovules, in particular where on the plant they were attached, is extremely limited. The traditional view was that the ovules were directly attached to the vegetative fronds (e.g. Stidd 1981) but when this model was tested (Seyfullah \& Hilton 2009) the supporting empirical evidence was found to be weak. This is a major problem as position of ovule attachment is regarded as a key character in phylogenetic studies of early seed plants (e.g. Crane 1985, Doyle \& Donoghue 1992, Hilton \& Bateman 2006).

Although organic attachment of ovules would be the "gold standard" evidence for solving this problem, some indirect evidence has recently come to light. Specimens from the Middle Pennsylvanian Sydney Mines Formation of Cape Breton, Canada documented by Cleal et al. (2010) suggested that Alethopteris-bearing medullosalean plants bore ovules on specialised fertile fronds lacking vegetative lamina. As pointed out in that paper, however, although the regular arrangement of the ovules relative to the axes was strongly suggestive, direct connection between them could not be confirmed; it seemed that compression and coalification du- ring fossilisation may have just slightly pulled the ovules away from the rachis. However, in the present paper we document another specimen, this time from Romania, which appears to corroborate the Canadian evidence.

The specimen originated from the Upper Pennsylvanian Reşiţa Formation (Bucur 1991, 1997) of the Reşiţa Basin, belonging to the Getic Nappe, in the southern Carpathian Mountains, Romania. It was collected from the sterile dump of Secu, a former coal mining locality close to Reşiţa town, Caraş-Severin County in the Banat historical province of Romania (Fig. 1). The Reşița Formation is a continental unit yielding several coal seams which were extracted in Secu and Lupac, in the northern part of the Reşița Basin (Năstăseanu 1987, Năstăseanu et al. 1973, Petrescu et al. 1987, Popa 2001, 2005, 2009, Popa \& Psenicka 2010). The Reşiţa Formation includes three members (the Doman, Lupacu Bătrân and Lupac members), but in the eastern part of the Reşița Basin, where Secu occurs, they cannot be differentiated (Fig. 1). The age of the Reşiţa Formation in Secu is Westphalian D - Stephanian B (Popa 2005). The sterile dump of Secu is particularly rich in well preserved fossil plants and arthropods (Androne et al. 2000, Popa 2005, 2009, Jarzembowski 2008), a future Site of Special Scientific Interest (SSSI).

\section{MATERIAL AND METHODS}

The hand specimen yielding the plant material belongs to the historical collections of the University of Bucharest, Laboratory of Palaeontology. Its collector is unknown and 


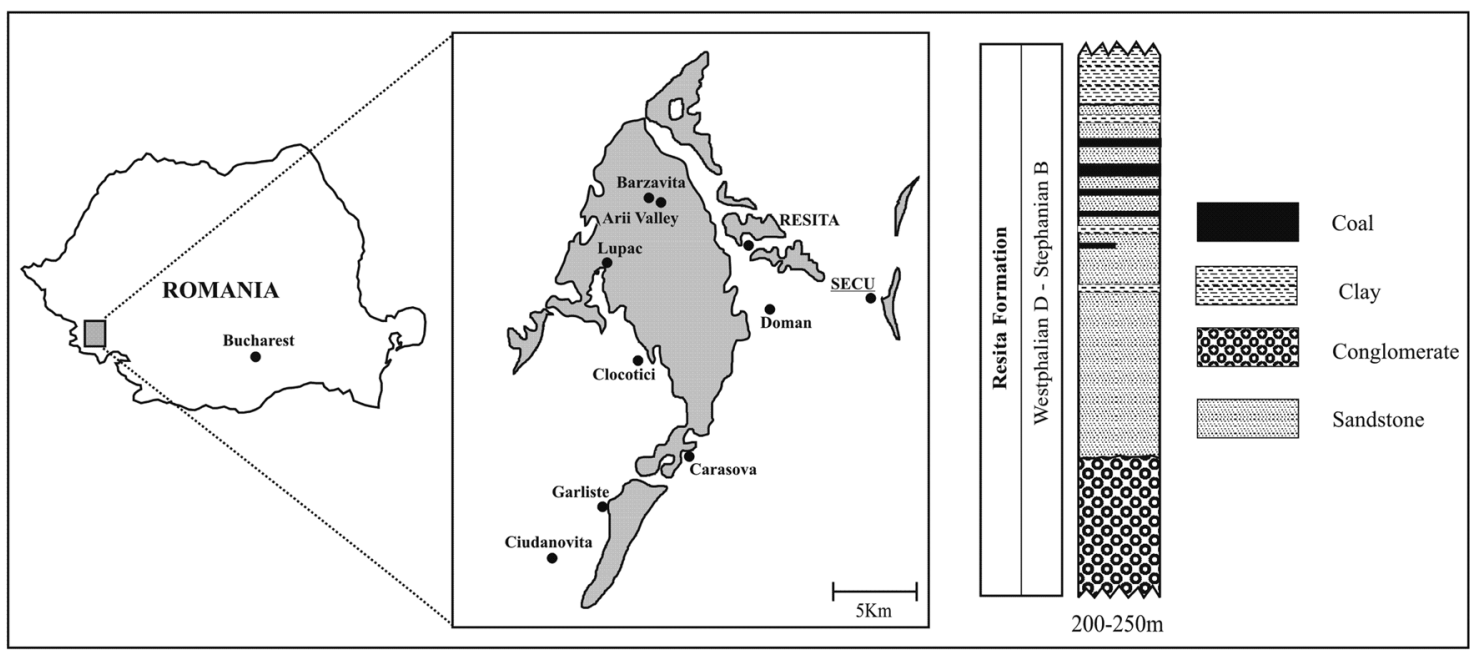

Figure 1 Occurrence of Secu locality, in the north-western part of the Reşiţa Basin, Getic Nappe, and stratigraphic log of the Reşiţa Formation, South Carpathians, Romania. Redrawn from Popa (2005)

has the inventory number LPBU0607, also bearing an older inventory number (1028). The old label indicates that the hand specimen possibly belonged to the TCA (Trustul de Cărbuni Anina) collection, a historical collection belonging to the Anina Coal Mine, Caraş-Severin County, Romania. The specimen is represented by a fine, carbonaceous sandstone slab full of fragments of Alethopteris zeilleri (Ragot ex Remy) Wagner, two Pachytesta incrassata Brongniart ex Renault and several fragments of Cordaites principalis (Germar) Geinitz (Fig. 2). The adpressions are well preserved but they yield no cuticles. The material was photographed with a Panasonic Lumix DMC-L10 with Olympus Digital Macro $35 \mathrm{~mm}$ lens, mounted on a Kaiser copystand with Ikea lateral lights (Popa 2011).

\section{DE S C R I P T I O N}

The specimen shows a $0.4 \mathrm{~m}$ long, straight, longitudinally striate rachis, $40 \mathrm{~mm}$ wide in its most proximal part. In the proximal part the rachis there is a medial, longitudinal ridge, but this rapidly changes into a longitudinal tear, dividing it into what seem to be $14 \mathrm{~mm}$ and $16 \mathrm{~mm}$ wide strips. Towards the most distal preserved part of the specimen, these two strips of rachis are $40 \mathrm{~mm}$ apart (Fig. 2). Numerous pinna fragments are preserved in association with this main rachis, but no unequivocal evidence of attachment was seen. These pinna fragments have linguaeform pinnules, broadly attached to the rachis, up to $15 \mathrm{~mm}$ long and $6 \mathrm{~mm}$ wide (Fig. 3b, c), with a strong midvein and thick, broadly arched lateral veins. These pinnae correspond to the fossil-species Alethopteris zeilleri as documented by Wagner (1968).

On the right-hand side of the distal part of the main rachis, a large ovate ovule, $90 \mathrm{~mm}$ long and $35 \mathrm{~mm}$ wide; it is widest just below the middle of the ovule. In the proximal part of the ovule, there is a swollen area, $30 \mathrm{~mm}$ long and $25 \mathrm{~mm}$ wide, probably representing the sclerotesta. The tissue surrounding this sclerotesta is flattened and may be interpreted as the sarcotesta. The chalazal end of the ovule lies next to the thick rachis but organic connection is difficult to unequivocally verify (Fig. 3a).

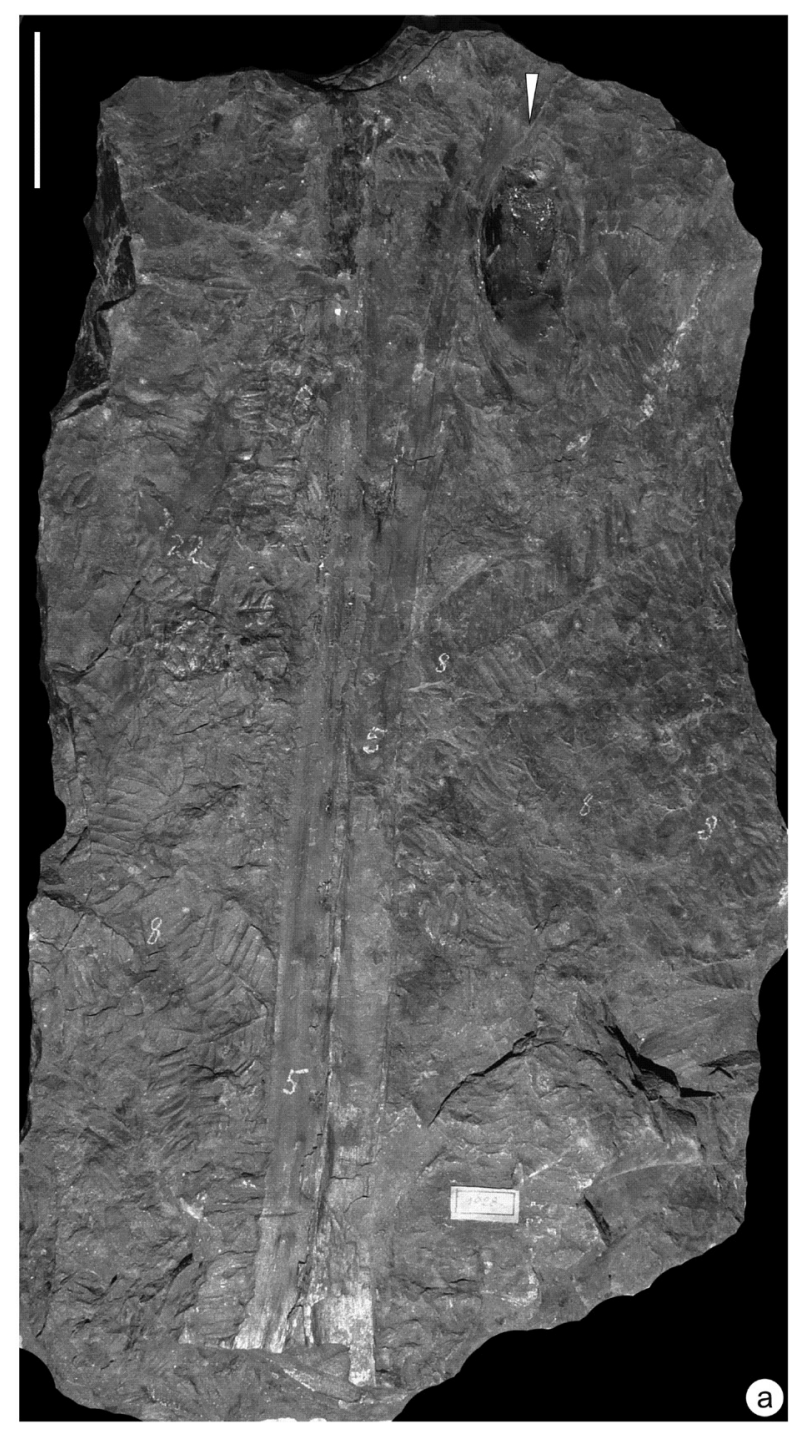

Figure 2 General view of the hand specimen LPBU0607, with a large petiole (marked with no. 5), Alethopteris zeilleri (marked with nos. 22), Pachytesta incrassata (arrowhead pointing to the chalazal, basal part of the seed) and Cordaites pricipalis (marked with no. 22). The white labels indicating plant fragments as well as the paper label marked with "1028" are historical. Secu, Reşița Basin, Romania. Scale bar: $100 \mathrm{~mm}$ 

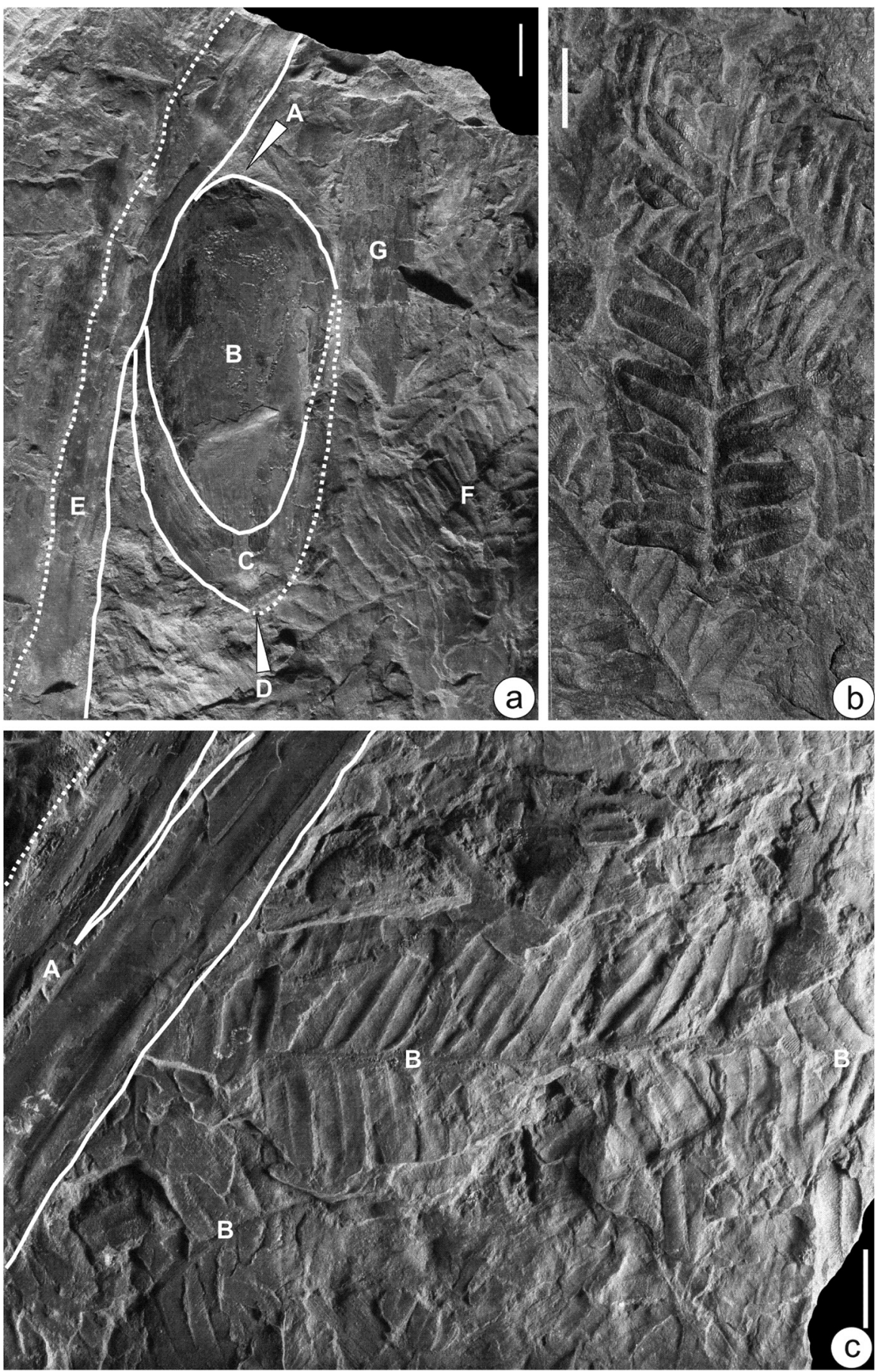

Figure 3 a - Pachytesta incrassata ovule next to Alethopteris zeilleri. A: Basal (chalazal) part of the megaspore; B: megaspore; C: pollen chamber; D. micropyle position; E: right arm of the fork, split longitudinally (dotted line); F: Alethopteris zeilleri fragment; G: Cordaites principalis fragment; b, c. Alethopteris zeilleri. A: split (forked) petiole, also hand labeled as "5"; B: Alethopteris zeilleri pinnae fragments, one hand labeled as "8". Hand specimen LPBU0607, Secu, Reşița Basin, Romania. Scale bar: $10 \mathrm{~mm}$

\section{DISCUSSION}

Although there is no pinnate foliage definitely attached to this rachis, the presence of only Alethopteris zeilleri pinnae in such profusion is highly suggestive. Moreover, as pointed out by Cleal et al. (2010) such large ovules have only ever been found in association with the Alethopteris zeilleri / A. psendograndinioides Zodrow \& Cleal complex of foliage species. The Romanian ovule is at the lower end of the size range of the anatomically-preserved species Pachytesta incrasata, which Cleal et al. (2010) argued probably originated from the same plants as produced Alethopteris zeilleri foliage.

It is of course always possible that the occurrence of large ovules very close to thick medullosalean rachises seen in both the Romanian and Canadian specimens is coincidental; in both cases the ovules may just have fallen in the sediment adjacent to the rachises by chance. In our view, however, this would seem unlikely, especially given that in both cases the ovules lie with their chalazal ends next to the rachis, as would be expected if the ovules were originally attached. These specimens indicate that the ovules were laterally attached to wide rachises: at least in these medullosaleans ovules were not borne terminally to pinnae, replacing terminal pinnules, but were laterally attached to rachises. The possible presence of vegetative pinnae would suggest that these were not specialised fertile fronds that only bore ovules, but were indistinguishable from the vegetative fronds except for the presence of ovules.

The most convincing attempts to reconstruct the Alethopteris frond architecture have been by Laveine (1986) and Laveine et al. (1992), who showed that they could be more than $7 \mathrm{~m}$ long, with a bifurcate pinnate architecture (sensu Laveine 1997). Given the width of the rachis in the Romanian specimen it seems most likely that it originated from a proximal position within the frond. The presence of abundant pinna fragments may indicate that it was from above the main dichotomy of the primary rachis near the base of the frond.

When trying to establish whole organism reconstructions of extinct plants, we would ideally use evidence of clear organic connection to establish relationships between different organs. Especially in adpression fossils, however, such evidence is likely to be elusive as the processes of compression will tend to pull plant parts apart even if they were still attached when entering the sediment. We must therefore sometimes look at evidence of close association between organs, especially where it can be documented in repeat occurrences such documented in the present paper. 


\section{CONCLUSION}

Although not clearly preserved in anatomical connection, the taphonomic position of the reproductive and vegetative structures preserved in the specimen LPBU0607 show a rare situation hinting that Alethopteris zeilleri and Pachytesta incrassata were produced by the same biological species of plant, but also to the idea that this type of medullosalean pteridosperm bore ovules within the proximal part of their fronds.

\section{ACKNOWLEDGEMENTS}

This paper is a contribution of the IGCP 575 "Pennsylvanian terrestrial habitats and biotas in south western Euramerica and northern Asia Minor and their relation to tectonics and climate".

\section{LITERATURE CITED}

Androne, P., V. Cirimbei \& M.E. Popa 2000. Paleozoic and Mesozoic botanical heritage values of the Reşiţa Basin, Romania. Analele Universității Bucureşti 49: 75-80.

Bucur, I.I. 1991. Proposition pour une nomenclature formelle des depots paleozoiques et mesozoiques de la zone de Reşiţa-Moldova Nouă (Carpathes Meridionales, Roumanie). Studia Universitatis Babes-Bolyai, Geologie 36: 3-14.

Bucur, I.I. 1997. Formațiunile mesozoice din zona Reşiţa-Moldova Nouă. Cluj-Napoca, 214 pp.

Cleal, C.J. 2008. Palaeofloristics of Middle Pennsylvanian medullosaleans in Variscan Euramerica. Palaeogeography, Palaeoclimatology, Palaeoecology 268: 164-180.

Cleal, C.J., E.L. Zodrow \& M. Mastalerz 2010. An association of Alethopteris foliage, Trigonocarpus ovules and Bernaultialike pollen organs from the Middle Pennsylvanian of Nova Scotia, Canada. Palaeontographica, Abt. B 283: 73-97.

Crane, P.R. 1985. Phylogenetic analysis of seed plants and the origin of angiosperms. Annals of the Missouri Botanical Garden 72: 716-793.

Dimichele, W.A., T.L. Phillips \& H.W. Pfefferkorn 2006. Paleoecology of Late Paleozoic pteridosperms from tropical Euramerica. Journal of the Torrey Botanical Society 133: 83-118.

Doyle, J.A. \& M.J. Donoghue 1992. Fossils and seed plant phylogeny reanalyzed. Brittonia 44, 89-106.

Hilton, J. \& R.M. Bateman 2006. Pteridosperms are the backbone of seed-plant phylogeny. Journal of the Torrey Botanical Society 133: 119-168.

Jarzembowski, E.A. 2008. The oldest insect from Romania: a new Carboniferous blattodean. Studia Geologica Polonica 129: 43-50.

Laveine, J.-P. 1986. The size of the frond in the genus Ale- thopteris Sternberg (Pteridospermopsida, Carboniferous). Geobios 19: 49-56.

Laveine, J.-P. 1997. Synthetic analysis of the neuropterids. Their interest for the decipherment of Carboniferous palaeogeography. Review of Palaeobotany and Palynology 95: 155-189.

Laveine, J.-P., A. Belhis, Y. Lemoigne \& S.Z. Zhang 1992. Frond architecture in the genera Neuralethopteris Cremer, Alethopteris Sternberg and Lonchopteris Brongniart (Carboniferous pteridosperms). Revue de Paléobiologie 6: 149166.

Năstăseanu, S. 1987. Upper Paleozoic molasse deposits in the Romanian South Carpathians. In: Pre-Variscan and Variscan events in the Alpine-Mediterranean mountain belts (E. Flugel, F. Sassi \& P. Grecula, eds.), pp. 371-378, Alfa Bratislava, Bratislava.

Năstăseanu, S., I. Stănoiu, C. Biţoianu 1973. Corelarea formaţiunilor molasei hercinice (Westfalian-Permian) din partea vestică a Carpaților Meridionali. Anuarul Institutului Geologic 40: 71-109.

Petrescu, I., E. Nicorici, C. Biţoianu, N. Țicleanu, C. Todros, M. Ionescu, G. Mărgărit, M. Nicorici, A. Duşa, I. Pătruțoiu, A. Munteanu, A. Buda 1987. Geologia zăcămintelor de cărbuni. 2. Zăcăminte din România. Editura Tehnică, Bucharest.

Popa, M.E., 2001. Aspects of Romanian Palaeozoic palaeobotany and palynology. Part I. An Acitheca type fern from Secu (Banat). Acta Palaeontologica Romaniae 3: 365-369.

Popa, M.E. 2005. Aspects of Romanian Palaeozoic palaeobotany and palynology. Part II. Overview of the Upper Carboniferous formations in the South Carpathians. Zeitschrift der Deutschen Gesellschaft fur Geowissenschaften 156: 415-430.

Popa, M.E. 2009. Late Palaeozoic and Early Mesozoic continental formations of the Reşița Basin. Editura Universității din Bucureşti, Bucharest, 197 pp.

Popa, M.E. 2011. Field and laboratory techniques in plant compressions: an integrated approach. Acta Palaeontologica Romaniae 7: 279-283.

Popa, M.E., J. Psenicka 2010. The Pennsylvanian Pecopteris ticleanui sp. nov. from Secu, Reşița Basin, Romania. Bulletin of Geosciences 85: 663-670.

Seyfullah, L.J. \& J. Hilton 2009. Re-evaluation of Halle's fertile pteridosperms from the Permian floras of Shanxi Province, China. Plant Systematics and Evolution 279: 191-218.

Stidd, B.M. 1981. The current status of medullosan seed ferns. Review of Palaeobotany and Palynology 32: 63-101.

Wagner, R.H. 1968. Upper Westphalian and Stephanian species of Alethopteris from Europe, Asia Minor and North America. Mededelingen van de Rijks Geologische Dienst, Serie C, III-1 6: 1-188. 